\title{
Should the poultry red mite Dermanyssus gallinae be of wider concern for veterinary and medical science?
}

\author{
David R George ${ }^{1,2}$, Robert D Finn ${ }^{1}$, Kirsty M Graham ${ }^{1}$, Monique F Mul ${ }^{3}$, Veronika Maurer ${ }^{4}$, Claire Valiente Moro ${ }^{5}$ \\ and Olivier AE Sparagano ${ }^{6^{*}}$
}

\begin{abstract}
The poultry red mite Dermanyssus gallinae is best known as a threat to the laying-hen industry; adversely affecting production and hen health and welfare throughout the globe, both directly and through its role as a disease vector. Nevertheless, D. gallinae is being increasingly implemented in dermatological complaints in non-avian hosts, suggesting that its significance may extend beyond poultry. The main objective of the current work was to review the potential of $D$. gallinae as a wider veterinary and medical threat. Results demonstrated that, as an avian mite, $D$. gallinae is unsurprisingly an occasional pest of pet birds. However, research also supports that these mites will feed from a range of other animals including: cats, dogs, rodents, rabbits, horses and man. We conclude that although reported cases of $D$. gallinae infesting mammals are relatively rare, when coupled with the reported genetic plasticity of this species and evidence of permanent infestations on non-avian hosts, potential for host-expansion may exist. The impact of, and mechanisms and risk factors for such expansion are discussed, and suggestions for further work made. Given the potential severity of any level of host-expansion in D. gallinae, we conclude that further research should be urgently conducted to confirm the full extent of the threat posed by D. gallinae to (non-avian) veterinary and medical sectors.
\end{abstract}

Keywords: Gamasoidosis, Dermanyssus gallinae, Avian mite dermatitis, Host expansion, Non-host feeding

\section{Background}

All animals and plants are susceptible to attack by parasites, with most being at least relatively host-specific [1]. Host specificity is by no means universal amongst ectoparasites, however, with some of the most significant species (e.g. mosquitoes and ticks) displaying highly generalist host ranges spanning multiple taxonomic classes $[2,3]$.

In domesticated birds, ectoparasitic mites are a particular issue with Dermanyssus gallinae being ubiquitous as a poultry pest throughout much of the globe [4]. Though $D$. gallinae are reported to be avian-specific, albeit infesting more than 30 species of wild birds [5], increasing reports of attacks on non-avian hosts may be indicative of host expansion. Such events are not uncommon among

\footnotetext{
* Correspondence: Olivier.sparagano@coventry.ac.uk

${ }^{6}$ Coventry University, Vice-Chancellor Office, Coventry CV1 5FB, UK

Full list of author information is available at the end of the article
}

invertebrates, being most often recorded in phytophagous insects. The dipteran Tephritis conura, for example, has been recently observed to have expanded its host range in N. Britain to include marsh thistle (Cirsium palustre) as well as its 'standard' host plant melancholy thistle (Cirsium heterophyllum) [6]. A Kenyan population of the Brassica 'specialist' Plutella xylostella provides an even more striking example of inter-family host expansion, having been recorded as infesting peas in 1999, causing heavy losses in this leguminous crop thereafter [7]. For haematophagous insects fewer examples of expansion exist. Nevertheless, numerous studies support generalism in host choice as having evolved from specialism, countering the argument that the latter is a dead-end strategy, and supporting host expansion per se as plausible in all specialist feeders [1]. Increased travel and trade, coupled with present and expected impacts of

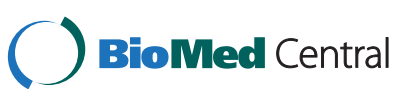

(C) 2015 George et al.; licensee BioMed Central. This is an Open Access article distributed under the terms of the Creative Commons Attribution License (http://creativecommons.org/licenses/by/4.0), which permits unrestricted use, distribution, and reproduction in any medium, provided the original work is properly credited. The Creative Commons Public Domain Dedication waiver (http://creativecommons.org/publicdomain/zero/1.0/) applies to the data made available in this article, unless otherwise stated. 
climate change, can be expected to facilitate hostexpansion events further in many species, increasing encounter rates with novel hosts and potentially favouring parasite virulence [8]. Increasing densities of humans and associated livestock/companion animals may make medical and veterinary systems particularly susceptible to host expansion events, where increased host occurrence logically favours rising encounter rates with novel parasites [8].

Interestingly, $D$. gallinae has already been found to 'switch' more readily between avian hosts of different species than several other related species within the same genus [9]. When removed from hens and offered canaries as a host, $D$. gallinae readily switched between the two, whereas Dermanyssus longipes could not. Dermanyssus carpathicus was able to switch between hosts, but only after suffering high initial losses not seen with $D$. gallinae [9]. This apparent tendency for higher switching success may reflect the generally broader host range of $D$. gallinae as compared to other species in the genus Dermanyssus [5].

Increasing reports of bird-mite attacks on humans and mammalian companion animals (see following Chapters) suggest that avian mite ectoparasitosis/dermatitis (gamasoidosis) may be of increasing medical and veterinary concern. Though several species of bird mite from multiple genera may be responsible for gamasoidosis, $D$. gallinae is most commonly implemented as the causal agent. The aim of this paper was to review past and current cases of $D$. gallinae infestation in non-poultry hosts and, based upon both this information and knowledge of mite biology and ecology, to explore whether $D$. gallinae should be considered as a present or emerging threat to wider veterinary and medical health. Though other avian mites are not explicitly considered, reference to other species is made for comparison.

\section{Review}

The poultry red mite, Dermanyssus gallinae

An in depth review of D. gallinae as a poultry pest, including sections on its biology and ecology has recently been published in the Annual Review of Entomology series [4]. Whilst there would be little to merit repeating this information in detail, a brief account of this mites' life history traits and current accepted significance is still required to place $D$. gallinae in context as a pest per se.

D. gallinae poses a significant threat to egg laying hens in many parts of the world, including the US, Europe, Japan and China [10-12]. In Europe infestation rates average more than $80 \%$ (see Figure 1), with costs associated with both control and production losses estimated at $€ 130$ million per year for the EU egg industry [13]. Production losses are driven by stress to birds and mite populations that may be so high as to result in anaemia and even death of hens by exsanguination [14-16]. Infestation can also lead to declines in egg quality (through increased shell thinning and spotting) and egg production $[10,15,17]$. Even small mite populations may have significant impact as $D$. gallinae may serve as a disease vector [18-20], with any individual mite potentially harbouring multiple pathogens [20]. Although the absolute vector competence of D. gallinae is unconfirmed, their potential to spread disease should not be underestimated [18].

The rapid life cycle of $D$. gallinae undoubtedly contributes to its status as a pest. Complete development from egg to adult typically occurs over two weeks, though may take place in less than half this time [21,22] (Figure 2). Temperatures of $10-35^{\circ} \mathrm{C}$ and high relative humidity (>70\%) facilitate D. gallinae reproduction and development $[22,23]$ and weekly doubling of populations is possible in egg-laying facilities where these conditions are often met $[22,24]$. Resulting $D$. gallinae densities typically reach 50,000 mites per bird in caged systems, though can escalate to 500,000 mites per bird in severe cases [16].

In egg-laying facilities $D$. gallinae are notoriously difficult to control for multiple reasons, one of these being the tendency of mites to seek refuge in poultry house substructures when not feeding. The majority of the D. gallinae lifecycle is spent off the host where mites aggregate together in response to both thigmokinesis and pheromone cues $[25,26]$. From these refugia $D$. gallinae locate their hosts using a combination of temperature stimuli, chemical signals and responses to vibration and carbon dioxide [27-30]. Once upon a host, mites feed for short periods of up to an hour, doing so every 2-4 days and typically (though not exclusively) during periods of darkness [31,32]. Larvae do not feed and though adult males may, they are thought to do so only intermittently [10]. Though feeding is required to permit reproduction and development of some stages, D. gallinae may survive for extended periods without a blood meal, permitting survival for up to 9 months when hosts are absent [23]. The development of pesticide resistance in D. gallinae also makes control challenging. Resistance to carbamates and pyrethroids has been widely reported and observed in $D$. gallinae from the UK [33,34], Sweden [35], France [36] and Italy [37]. In a survey of British farms published in 2004, more than $60 \%$ had experienced acaricide-resistant infestations [38] and figures have likely worsened since [4] (Table 1).

\section{Veterinary significance}

As an avian mite recorded from numerous bird hosts it is of little surprise that $D$. gallinae may pose a threat to domestic fowl other than poultry [5]. Companion birds, such as hobby pigeons and budgerigars are also at risk and in canaries D. gallinae has even been linked to infection with the bacteria Chlamydia psittaci [56]. 


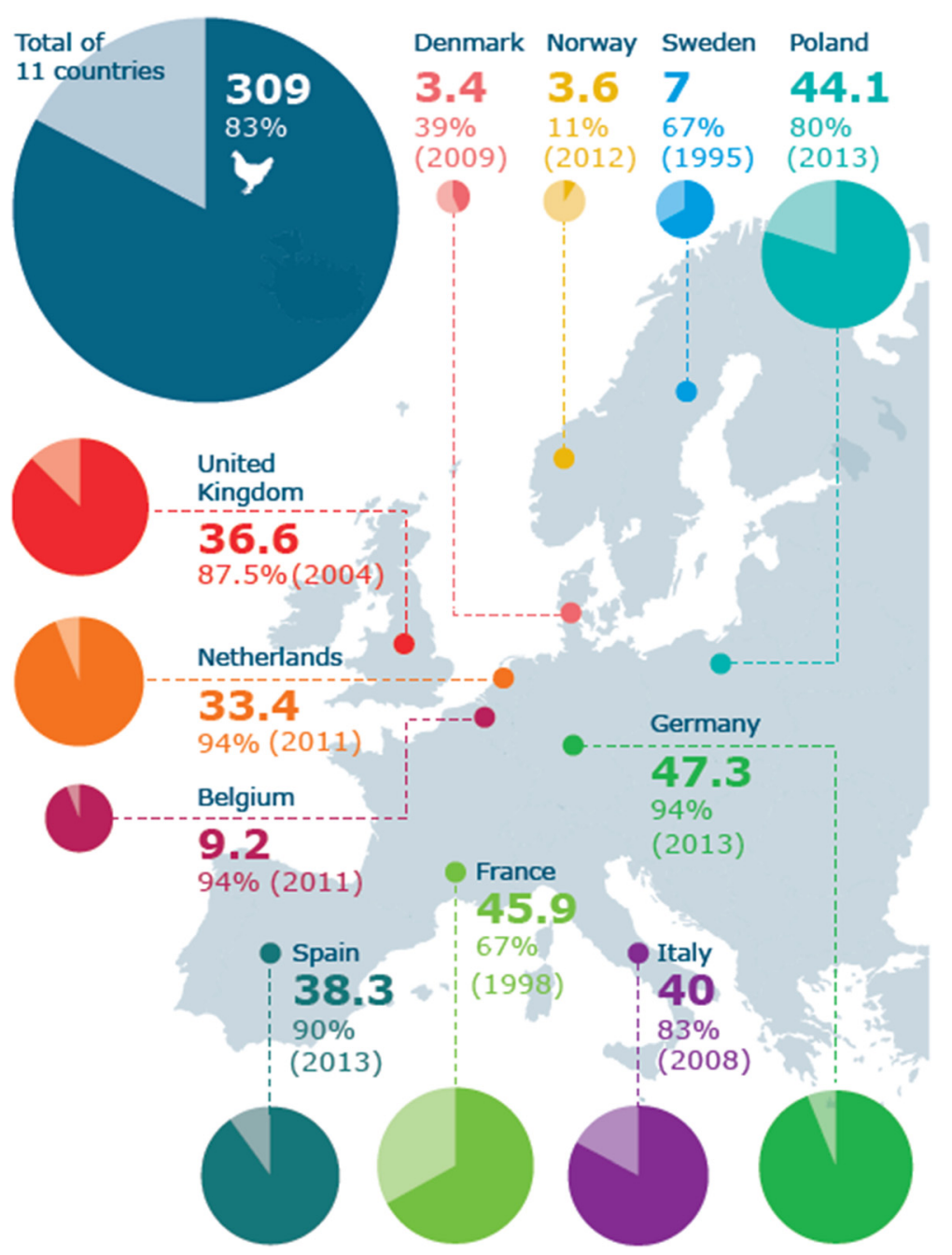

Figure 1 Number of laying hens per country in millions (2012) and the percentages of farms infested by Dermanyssus gallinae.

Image reproduced from Mul; OWageningen UR Livestock Research.

Though not necessarily commonplace, reports of D. gallinae associated with non-avian companion animals do exist. Several references have been made in the literature to suggest that $D$. gallinae will feed from dogs and cats [57-59], with mites also assigned as the causal agent of dermatitis in a 16 year-old domestic horse [60]. D. gallinae have also been recovered from goats during skin sampling for mange mites [61], and from mice resident in poultry houses [62]. Such reports, however, do not necessarily confirm infestation of these species; $D$. gallinae may, for example, have been present on goats/mice without feeding from them. Even in work confirming D. gallinae as the cause of equine dermatitis, it's important to note that the horse in question was housed in close proximity to poultry providing the opportunity for this condition to have arisen through repeated adventitious feeding, rather than permanent infestation. Nevertheless, under more controlled laboratory conditions, work supports that D. gallinae can and will feed from both mice and rabbits [63], with other work confirming permanent infestation of rodents (gerbils) in the absence of birds that may have otherwise served as a primary host [64]. In later work the ability of D. gallinae to subsist on the blood of numerous vertebrate species was demonstrated where these mites "engorged in vitro on the blood of quail, chickens, sheep, calves, pigs, and rabbits" [65]. This same work, however, showed that when offered blood of these different animals through different skin membranes "mites fed satisfactorily only through the skin of birds." [65].

The above work perhaps suggests that the skin surface presents more of a barrier to mammalian feeding in $D$. gallinae than non-avian blood. Based on the above reports, however, it seems that this barrier can be overcome, with (at least) adventitious feeding in vivo perhaps 


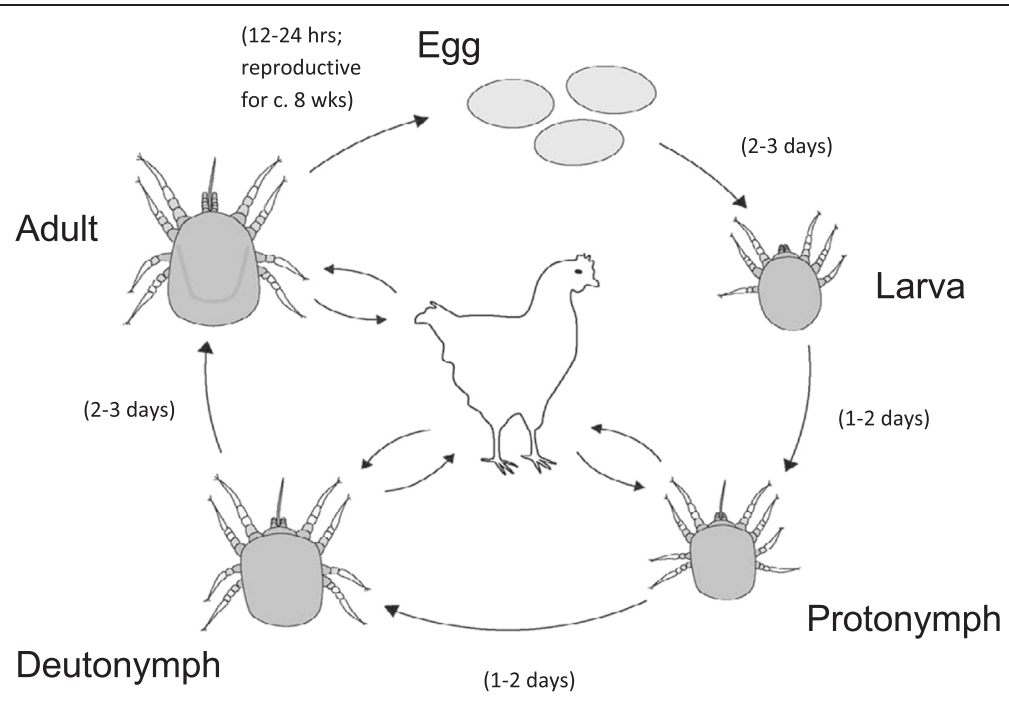

Figure 2 Life cycle of Dermanyssus gallinae. Eggs are laid in clutches (4-8 eggs) in refugia where larvae may remain without feeding prior to their first moult. Each female may lay up to eight clutches of eggs in-between feeding bouts, typically laying around 30-50 eggs in a lifetime. Image adapted from Maurer [39].

Table 1 Bacterial and viral pathogens 'associated' (see table) with Dermanyssus gallinae

\begin{tabular}{|c|c|c|c|}
\hline & Pathogen & Association & $\begin{array}{l}\text { Related } \\
\text { references }\end{array}$ \\
\hline \multirow[t]{7}{*}{ Bacteria } & Salmonella gallinarum & Isolated from mites & {$[40]$} \\
\hline & Pasteurella multocida & $\begin{array}{l}\text { Transmission } \\
\text { demonstrated }\end{array}$ & {$[41]$} \\
\hline & $\begin{array}{l}\text { Erysipelthrix } \\
\text { rhusiopathiae }\end{array}$ & Isolated from mites & {$[42]$} \\
\hline & $\begin{array}{l}\text { Listeria } \\
\text { monocytogenes }\end{array}$ & Isolated from mites & {$[43]$} \\
\hline & Coxiella burnetii & $\begin{array}{l}\text { Transmission } \\
\text { demonstrated }\end{array}$ & {$[44]$} \\
\hline & Nocardia brasiliensis & Isolated from mites & [19] \\
\hline & Mycoplasma synoviae & Isolated from mites & {$[20]$} \\
\hline \multirow[t]{7}{*}{ Viruses } & Newcastle disease & Isolated from mites & {$[45]$} \\
\hline & Fowlpox virus & $\begin{array}{l}\text { Transmission } \\
\text { demonstrated }\end{array}$ & {$[46,47]$} \\
\hline & St. Louis encephalitis & Isolated from mites & {$[48-50]$} \\
\hline & $\begin{array}{l}\text { Tick bourne } \\
\text { encephalitis }\end{array}$ & Isolated from mites & {$[51]$} \\
\hline & $\begin{array}{l}\text { Eastern equine } \\
\text { encephalitis }\end{array}$ & $\begin{array}{l}\text { Transmission } \\
\text { demonstrated }\end{array}$ & {$[52]$} \\
\hline & $\begin{array}{l}\text { Western equine } \\
\text { encephalitis }\end{array}$ & $\begin{array}{l}\text { Transmission } \\
\text { demonstrated }\end{array}$ & {$[53]$} \\
\hline & $\begin{array}{l}\text { Venezualan equine } \\
\text { encephalitis }\end{array}$ & $\begin{array}{l}\text { Transmission } \\
\text { demonstrated }\end{array}$ & {$[54]$} \\
\hline
\end{tabular}

Table based on information originally published by Valiente Moro et al. $[18,55]$ and updated with data from Chu et al. [20]. representing a first step towards host expansion, as occasionally evidenced by permanent infestations on nonavian, seemingly primary hosts.

\section{Medical significance}

According to data presented in Table 2, reports of gamasoidosis have increased in frequency in recent years, particularly in residential settings in association with synanthropic birds. Further reports have appeared in the literature since this data was compiled, with D. gallinae recently confirmed as the causal agent of gamasoidosis in five members of a Serbian household [66]. Though numerous cases of gamasoidosis, typically linked to nearby feral birds' nests and often resulting in dermatological complaints of one kind or another, have been reported for $O$. sylviarum or avian mites in general, D. gallinae are most commonly identified as the causal agent (Table 2). D. gallinae have also been reported as posing a risk to poultry workers, so much so that this work proposes their presence as an 'occupational hazard' [67]. For D. gallinae at least, this body of literature, though currently small, confirms ingestion of human blood [68], propensity for persistent infestation when feeding on human blood alone [69] and geographically wide-spread occurrence on a global scale. That $D$. gallinae is assigned responsibility for the majority of gamasoidosis cases is perhaps unsurprising, with laboratory study demonstrating that these mites can be induced to feed upon humans, albeit at low levels, whereas other avian-ectoparasitic mites (Ornithonyssus (syn. Bdellonyssus) spp) cannot [63] (though see [70]).

Though reports of gamasoidosis are still relatively uncommon, unpublished accounts suggest that in some areas 
Table 2 Cases of human attack by avian mite species documented in scientific literature from 1936 to 2013

\begin{tabular}{|c|c|c|c|c|}
\hline Mite species & Details & 1936-1961 & 1962-1987 & $1988-2013$ \\
\hline \multirow[t]{4}{*}{ Dermanyssus gallinae } & Residential & $6[68,76-79]$ & $1[80]$ & $18[64,81-89]$ \\
\hline & Hospitals & - & $6[90-94]$ & $1[95]$ \\
\hline & Office spaces & - & $2[96,97]$ & $2[82]$ \\
\hline & Occupational* & - & - & $4[69,81,98,99]$ \\
\hline \multirow[t]{2}{*}{ Dermanyssus spp. or other species } & Residential & - & $1[100]$ & $2[74,101]$ \\
\hline & Occupational & - & - & 1 [102] \\
\hline \multirow[t]{3}{*}{ Ornithonyssus sylviarum/Ornithonyssus spp. } & Residential & $1[103]$ & $4[70,104-106]$ & $8[64,81,107-111]$ \\
\hline & Hospitals & - & $1[94]$ & - \\
\hline & Occupational & - & - & $1[112]$ \\
\hline Avian mite complex & Residential & $3[73,113,114]$ & $1[115]$ & $2[86,116]$ \\
\hline
\end{tabular}

Figures show number of independent cases (by mite population), though any given reference may provide multiple cases from a single mite population.

*'Occupational' includes hobby poultry keepers.

(such as Hawaii) bird mites per se have become strongly associated with humans over a relatively short period $(<10$ years), this being indicative of host expansion (Eco Smart Pest Control, personal communication). More generally, cases of gamasoidosis have been reported since the 17th century [71], documented in the leading medical literature since at least the 1920s [71,72] and reviewed in the last 15 years [64], yet the full extent of gamasoidosis as a threat to human health has still to be explored through empirical research.

The potential medical significance of D. gallinae is exacerbated by the fact that these mites can carry and transmit zoonotic diseases of both bacterial and viral origin (Table 1). Though the vector capacity of $D$. gallinae is still an emerging science, mite-bird transmission has been demonstrated in a number of cases [55], increasing the likelihood that relevant diseases carried may also be passed from birds to mammals, humans included. Examples of diseases spread to humans through bird mite vectors are rare in the literature, though transmission of spirochetes, rickettsiae, salmonellae, bartonellae, pasteurellae, sporozoa, hemogregarines, flagellates, and filariae have all been suggested [73]. More recent evidence supports acquisition of Bartonella via Dermanyssus spp [74]. Worryingly, in a preliminary survey of one internet user group, comprised of past and present gamasoidosis sufferers, more than a third of cases reported associated contraction of Lyme disease, Bartonella and/or Babesia [75]. Fungal infection was also reported as an associated condition, though it is unclear if this resulted from infestation, or was a pre-existing 'risk factor' rendering those affected susceptible to avian mites (see later). Accounts also reported persistent infestations, lasting for many years in extreme cases, despite varied and vigorous treatment interventions. Though hyper-sensitisation could explain symptom persistence, an average infestation longevity of $>3$ years [75] suggests this to be unsatisfactory as an explanatory hypothesis in all cases.

\section{Discussion}

\section{Scale of the threat}

Despite its potential significance, little research had been conducted on the threat of gamasoidosis to non-avian animal and human health, with the bulk of work being formed of case studies documenting occurrence only. Where medical significance is concerned, this is in stark contrast to work undertaken with other (primarily) veterinary ectoparasites of medical concern (e.g. biting flies and ticks); this probably reflects the historically low prevalence of gamasoidosis in comparison.

Diagnosis of gamasoidosis is difficult, whether the mite species involved is D. gallinae or otherwise. Considering that at least 25 species of Dermanyssus have been described [9], even confirming species within this single genus is troublesome. Several authors have tried to analyse the synanthropic versus wild-environment species, also considering how host-Dermanyssus species were organised. Molecular phylogeny studies found that environmental conditions (such as the use of acaricides or pesticides on farms) can influence $D$. gallinae populations, which may consequently show higher diversities regionally than between countries $[9,117]$. At least two D. gallinae clades have been described to date, showing that populations in poultry farms can be organised into several lineages [118]. Work in Sweden and Norway identified several haplotypes of $D$. gallinae, finding wild-type and syanthropic mites to be genetically distinct [119]. This apparent genetic plasticity, coupled with minimal crossbreeding between syanthropic and wild-type mites, may lend itself to host-switching in D. gallinae, allowing populations to quickly adapt to novel, even non-avian hosts. 
In cases of human infestation, positive identification of species (or at least functionally similar groups based on lifehistory patterns) and recommendation of suitable treatment requires an understanding of mite taxonomy and ecology that many healthcare professionals and pest control organisations do not currently possess [88]. Diagnosing infestations based on presenting symptoms (as is often undertaken) is inadequate and a suspected cause of large-scale misdiagnosis for similarly-presenting parasitoses such as scabies and pediculosis, general dermatitis or physiological conditions including delusional ectoparasitosis $[64,83,95]$. Infestation with other mite species, such as Demodex mites, may also present similarly [120] as may conditions related to exposure to mite allergens [121]. Confirming infestations based on blood testing is also difficult, with current techniques only being able to ascertain whether the host is responding to mites per se. Developments in this area to uncover host markers specifically for $D$. gallinae would be useful, though may be hampered as these mites are thought to adopt a feeding strategy of minimal interference [122]. Diagnosing D. gallinae in companion or livestock animals is likely to be equally problematic, with other ectoparasitic mites (such as the mange mite Sarcoptes scabiei) being far more common on these hosts and presenting similarly. Available tools to assist clinicians in diagnosing gamasoidosis per se do exist (e.g. [123]), though the extent to which such material is consulted is unknown.

It is consequently difficult to predict the current extent of gamasoidosis and increased effort needs to be focused in this area. We speculate that although persistent infestations are likely to be relatively rare, population development of D. gallinae on human, livestock and (non-avian) companion animal hosts may be possible if certain conditions are met, these perhaps relating most crucially to host immunosuppressive function and the consequent breakdown of mite feeding deterrence at the skin surface (see below).

\section{Associated risk factors}

The apparent co-occurrence of gamasoidosis and various immunosuppressive disorders [75] indicates that bird mites are more likely to attack and develop persistent populations on human hosts with a weakened immune response. In other ectoparasitic mites a relationship between increased severity of infestation and immunosuppression is better supported. The primary risk factor for crusted (or Norwegian) scabies in humans, for example, is recognised as immunodeficiency [124]. Host defences are commonly cited as a driver for parasite specificity [2], further suggesting that their breakdown could facilitate attack from a broader parasite fauna. Such a relationship between immunosuppression and gamasoidosis, should it exist, could explain apparent anomalies associated with many reports of this condition; such as why relatively few poultry workers report problems with gamasoidosis and why the condition may affect some members, but not others, of the same household. It would also support special consideration of gamasoidosis as a threat in sectors such as hospitals, neonatal units and nursing homes, particularly among those afflicted by, or receiving immunosuppressive treatment for, conditions such as HIV and cancer, or with natural immunodeficiency as a result of pregnancy or neurological/developmental disorders. Accepting such a relationship also raises the interesting question as to whether apparent increased incidence of gamasoidosis in recent years could be a result of improvements in healthcare allowing for prolonged survival of those suffering from immunosuppression.

According to work presented earlier, the skin surface of mammals appears to represent the limiting factor to $D$. gallinae non-host feeding, with ingestion of mammalian blood through an avian skin membrane being acceptable to these mites, at least in terms of development, moulting and oviposition [65]. Accepting the above link between gamasoidosis and immunodeficiency, it is therefore logical to surmise that a decrease in immune function at the skin surface is sufficient to promote persistent $D$. gallinae infestations on non-avian hosts. Interestingly, many of the respondents to a recent survey [75] reported fungal skin infections co-occurring with D. gallinae infestation, which would support a hypothesis that persistent mammalian infestation by this species is only limited by the immune response at the skin surface (with fungal skin infection being indicative of this failing). Among healthy humans antimicrobial agents are produced at the skin surface. These include human $\beta$-defensins, cathelicidin LL-37, lysozyme, RNase 7, elafin, psoriasin, dermicin, adrenomedullin, secretory leukocyte protease inhibitor and neutrophil gelatinase-associated lipocalin, that protect the skin by targeting foreign biota [125]. Similar skinsurface products act against mosquitos in a number of ways, repelling, deterring or even confusing (e.g. blocking) host seeking processes [126]. Any breakdown/imbalance in the production of these, or similar products, could be the 'smoking gun' for gamasoidosis susceptibility, rendering individuals more acceptable to $D$. gallinae (and, potentially, other avian mites) based on changes in skin surface chemistry. It also deserves note, however, that gamasoidosis can occur in seemingly healthy individuals, affecting entire households equally [66]. This suggests that though immunosuppression may increase susceptibility, it is not necessarily a pre-requisite for infestation. This a deserving and interesting area for future research into this little-studied condition, both in humans and other non-avian hosts.

Even in the presence of an immunocompromised novel host, D. gallinae would still need to accept a foreign skin surface through which to feed, with preference alone thought to restrain host range in some parasites [2]. In 
work to develop synthetic skin surfaces for $D$. gallinae in vitro culturing, engorgement through 'foreign' membranes is supported [127], though higher feeding rates are typically achieved when these are impregnated with kairomones from an avian host (such as skin or feather extracts) $[28,127]$. More generalist cues, including temperature, vibration and $\mathrm{CO}_{2}$, may also play a role in the host selection process $[27,29,30]$, potentially promoting (at least) attraction to any warm, respiring host. Adaption to novel cues that precede an otherwise appropriate stimulus in the host location/selection process may occur rapidly in invertebrates through 'learning' [128], suggesting that $D$. gallinae could 'learn' to associate non-host skin with a blood-meal if the host selection process permitted feeding. Thus, we postulate that even low-level exploratory feeding through non-deterrent foreign membranes, such as human skin in immunocompromised subjects, could promote host expansion in D. gallinae (see Figure 3), particularly when combined with a seemingly generalist approach to host location (above), and an ability to process a non-avian blood-meal per se [63-65,69].

\section{Treating infestations}

Based on the available literature, terminating the majority of D. gallinae infestations in humans appears relatively straight-forward once a positive diagnosis has been made. D. gallinae are principally regarded as an environmental pest, typically associated with synanthropic birds as their primary hosts, particularly feral pigeons [84]. In most reported cases removal of these birds from nesting or roosting sites in the vicinity of afflicted patients, with or without subsequent acaricide treatment of the area, is sufficient to arrest infestations, with any continued development of infestations on a diet of human blood assumed to be self-limiting. Nevertheless, and as previously noted, D. gallinae may develop on human blood [63] and cases of persistent infestation on human hosts do exist $[69,75]$.

Recommended treatments for persistant human infestations with $D$. gallinae (and other avian mites) principally include topical and premise-based pyrethroids, premisebased insect growth regulators and diatomaceous earths, and oral ivermectin, all of which have been reported to fail [75]. Recommending topical treatments for D. gallinae (that reside off-host) is inappropriate and unlikely to effectively target and eliminate infestation. The opposite would be true for O. sylviarum, however, highlighting the importance of positive diagnosis that extends beyond "gamasoidosis" per se in effective treatment prescriptions. Furthermore, it is widely known from poultry research that resistance to pyrethroids, as well as other standard acaricides, is now commonplace in D. gallinae, and the effect of diatomaceous earths on this mite may be highly variable [4]. Thus, alternative treatment by novel or biopesticides may be more successful in targeting $D$. gallinae $[129,130]$, and perhaps better accepted in a domestic setting for use by either humans or companion animals.

\section{Conclusion}

Though confirmed reports of persistent gamasoidosis in the absence of avian hosts remain rare, those that do exist highlight host expansion potential. Due to a paucity of studies on the topic, the risk of this occurring on a large scale remains unknown. It can be concluded, however, that D. gallinae pose a particular host expansion threat due to their genetic plasticity, relatively catholic host location process, willingness to at least feed adventitiously through foreign membranes and ability to process a nonavian blood-meal. That D. gallinae often persist in close proximity to man, livestock and/or companion animals is

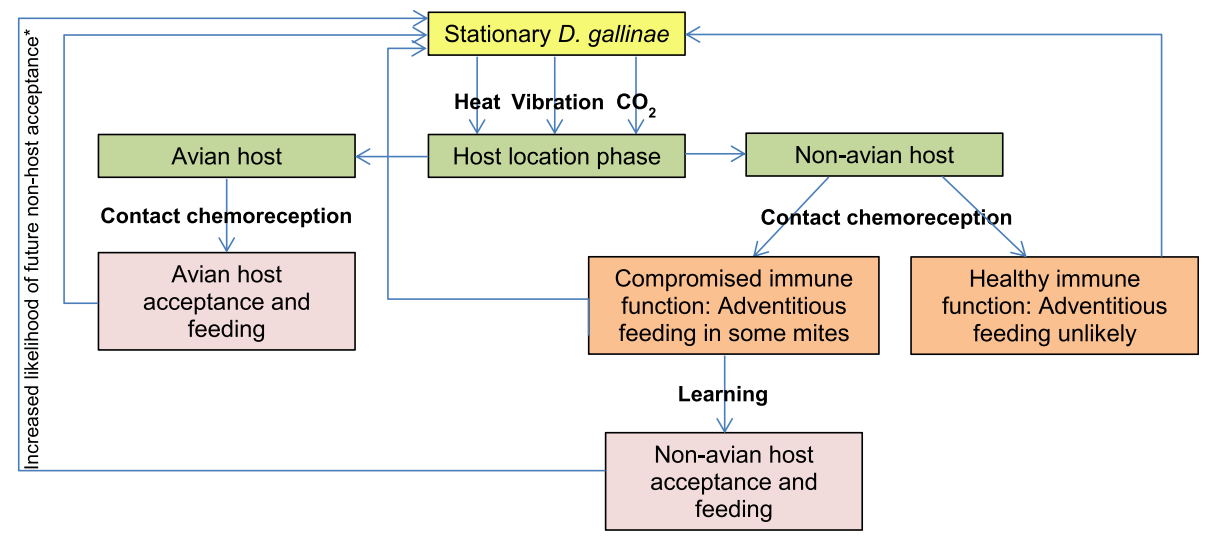

Figure 3 Theoretical host location, selection and acceptance processes for Dermanyssus gallinae on avian and non-avian hosts. Yellow: Dormant phase; Green: Host location phase; Orange: Host selection phase; Red: Host acceptance phase. Note the positive feedback loop for non-host acceptance and feeding which if sustained could potentially lead to a heightened chance of accepting non-avian hosts with healthy immune function. 
also of concern, optimising opportunistic non-avian feeding events and thus potentially increasing the likelihood of non-avian host acceptance. The continuing rise in global human populations (as well as those of associated livestock and companion animals) can be expected to exacerbate the issue, with resulting increased contact between parasites and novel hosts expected to facilitate host expansion and/or switching events [2].

With the advent of the internet and various usergroups/forums it can be at least tentatively surmised that as a medical condition gamasoidosis is underrepresented in the scientific literature [75], this being a probable result of the difficulty in diagnosing this condition. To effectively diagnose and treat gamasoidosis more research is needed. Work is most urgently required to confirm prevalence, determining the mite species involved and potential links to human disease. Also important are investigation of effective treatment interventions, particularly in light of reported issues with $D$. gallinae acaricide resistance in poultry [4] and repeated failure of prescribed treatments for gamasoidosis [75].

\section{Abbreviation}

EU: European Union.

\section{Competing interests}

The authors declare that they have no competing interests.

\section{Authors' contributions}

DG conceived the topic and prepared an initial draft based on conference presentations given by authors between 2012 and 2014. Data and figures were prepared by co-authors as shown in the text. All authors contributed to, read, critically reviewed and approved drafts of the manuscript prior to submission.

\section{Acknowledgements}

The authors gratefully acknowledge funding from Northumbria University as used to support DG (0.2FTE Research Fellow) and KG (former PhD student) during preparation of the manuscript. The authors would like to acknowledge networking support by the COST Action FA1404: COREMI - Improving current understanding and research for sustainable control of the poultry red mite Dermanyssus gallinae.

\section{Author details}

${ }^{1}$ Faculty of Health and Life Sciences, Northumbria University, Newcastle upon Tyne NE1 8ST, UK. ${ }^{2}$ Technology Centre, Cawood, Selby YO8 3TZ, UK. ${ }^{3}$ Wageningen UR Livestock Research, Wageningen, The Netherlands. ${ }^{4}$ Research Institute of Organic Agriculture FiBL, Frick, Switzerland. ${ }^{5}$ Ecologie Microbienne, UMR CNRS 5557, USC INRA 1364, VetAgro Sup, FR41 BioEnvironment and Health, Université Claude Bernard Lyon 1, Villeurbanne, France. ${ }^{6}$ Coventry University, Vice-Chancellor Office, Coventry CV1 5FB, UK.

Received: 31 December 2014 Accepted: 24 February 2015

Published online: 25 March 2015

\section{References}

1. Agosta SJ, Janz N, Brooks DR. How specialists can be generalists: resolving the "parasite paradox" and implications for emerging infectious disease. Zoologia-Curitiba. 2010;27:151-62.

2. Graham SP, Hassan HK, Burkett-Cadena ND, Guyer C, Unnasch TR. Nestedness of ectoparasite-vertebrate host networks. PLoS One. 2009:4:e7873.

3. Kiewra D, Lonc E. Epidemiological consequences of host specificity of ticks (Ixodida). Ann Parasitol. 2012;58:181-7.
4. Sparagano O, George DR, Harrington D, Giangaspero A. Biology, epidemiology, management and risk related to the poultry red mite, Dermanyssus gallinae. Annu Rev Entomol. 2014;59:447-66.

5. Roy L, Chauve CM. Historical review of the genus Dermanyssus Duges, 1834 (Acari: Mesostigmata: Dermanyssidae). Parasite. 2007;14:87-100.

6. Diegisser T, Tritsch C, Seitz A, Johannesen J. Infestation of a novel host plant by Tephritis conura (Diptera: Tephritidae) in northern Britain: host-range expansion or host shift? Genetica. 2009;137:87-97.

7. Löhr B, Gathu R. Evidence of adaptation of diamondback moth, Plutella xylostella (L.), to pea, Pisum sativum L. Int J Trop Insect Sci. 2002;22:161-73.

8. Budria A, Candolin U. How does human-induced environmental change influence host-parasite interactions? Parasitology. 2014;141:462-74.

9. Roy L, Dowling AP, Chauve CM, Lesna I, Sabelis MW, Buronfosse T. Molecular phylogenetic assessment of host range in five Dermanyssus species. Exp Appl Acarol. 2009;48:115-42.

10. Chauve C. The poultry red mite Dermanyssus gallinae (De Geer, 1778): current situation and future prospects for control. Vet Parasitol. 1998;79:239-45.

11. Sparagano O, Pavlicevic A, Murano T, Camarda A, Sahibi H, Kilpinen O, et al. Prevalence and key figures for the poultry red mite Dermanyssus gallinae infections in poultry farm systems. Exp Appl Acarol. 2009:48:3-10.

12. Wang FF, Wang M, Xu FR, Liang DM, Pan BL. Survey of prevalence and control of ectoparasites in caged poultry in China. Vet Rec. 2010;167:934-7.

13. Van Emous R. Wage war against the red mite! Poultry Int. 2005;44:26-33.

14. Wojcik AR, Grygon-Franckiewicz B, Zbikowska E, Wasielewski L. Invasion of Dermanyssus gallinae (De Geer, 1778) in poultry farms in the Torun region. Wiad Parazytol. 2000;46:511-5.

15. Cosoroaba I. Massive Dermanyssus gallinae invasion in battery-husbandry raised fowls. Rev Med Vet-Toulouse. 2001;152:89-96.

16. Kilpinen O, Roepstorff A, Permin A, Norgaard-Nielsen G, Lawson LG, Simonsen HB. Influence of Dermanyssus gallinae and Ascaridia galli infections on behaviour and health of laying hens (Gallus gallus domesticus). Br Poultry Sci. 2005;46:26-34

17. Van Emous RA, Fiks-Van Niekerk TGCM, Mul MF. €11 million damage for the sector: enquiry into the cost of mites to the poultry industry. De Pluimveehouderij. 2006;35:63-70.

18. Valiente Moro C, Chauve C, Zenner L. Vectorial role of some Dermanyssoid mites (Acari, Mesostigmata, Dermanyssoidea). Parasite. 2005:12:99-109.

19. Valiente Moro C, Thioulouse J, Chauve C, Normand P, Zenner L. Bacterial taxa associated with the hematophagous mite Dermanyssus gallinae detected by 165 rRNA PCR amplification and TTGE fingerprinting. Res Microbiol. 2009;160:63-70.

20. Chu TT, Murano T, Uno Y, Usui T, Yamaguchi T: Molecular detection of avian pathogens in poultry red mite (Dermanyssus gallinae) collected in chicken farms. J Vet Med Sci 2014, in press.

21. Axtell RC. Poultry integrated pest management; status and future. Integr Pest Manag Rev. 1999;4:53-73.

22. Maurer V, Baumgartner J. Temperature influence on life table statistics of the chicken mite Dermanyssus gallinae (Acari: Dermanyssidae). Exp Appl Acarol. 1992;15:27-40.

23. Nordenfors $\mathrm{H}$, Hoglund J, Uggla A. Effects of temperature and humidity on oviposition, molting, and longevity of Dermanyssus gallinae (Acari: Dermanyssidae). J Med Entomol. 1999;36:68-72.

24. Hoglund J, Nordenfors H, Uggla A. Prevalence of the poultry red mite, Dermanyssus gallinae, in different types of production systems for egg layers in Sweden. Poultry Sci. 1995;74:1793-8.

25. Entrekin DL, Oliver Jr JH. Aggregation of the chicken mite, Dermanyssus gallinae (acari: Dermanyssidae). J Med Entomol. 1982;19:671-8.

26. Koenraadt CJ, Dicke M. The role of volatiles in aggregation and host-seeking of the haematophagous poultry red mite Dermanyssus gallinae (Acari: Dermanyssidae). Exp Appl Acarol. 2010;50:191-9.

27. Kilpinen O, Mullens BA. Effect of food deprivation on response of the mite, Dermanyssus gallinae, to heat. Med Vet Entomol. 2004;18:368-71.

28. Zeman P. Surface skin lipids of birds - a proper host kairomone and feeding inducer in the poultry red mite, Dermanyssus gallinae. Exp Appl Acarol. 1988:5:163-73.

29. Kilpinen O. How to obtain a bloodmeal without being eaten by a host: the case of poultry red mite, Dermanyssus gallinae. Physiol Entomol. 2005;30:232-40. 
30. Kilpinen O. Activation of the poultry red mite, Dermanyssus gallinae (Acari: Dermanyssidae), by increasing temperatures. Exp Appl Acarol. 2001;25:859-67.

31. Maurer V, Bieri M, Fölsch DW. Das suchverhalten von Dermanyssus gallinae in Hühnerställen. Arch Geflügelk. 1988;52:209-15

32. Nakamae H, Fujisaki K, Kishi S, Yashiro M, Oshiro S, Furuta K. The new parasitic ecology of chicken mites Dermanyssus gallinae, parasitizing and propagating on chickens even in the daytime. J Poultry Sci. 1997;34:110-6.

33. Fiddes MD, Le Gresley S, Parsons DG, Epe C, Coles GC, Stafford KA. Prevalence of the poultry red mite (Dermanyssus gallinae) in England. Vet Rec. 2005;157:233-5.

34. Thind BB, Ford HL. Assessment of susceptibility of the poultry red mite Dermanyssus gallinae (Acari : Dermanyssidae) to some acaricides using an adapted filter paper based bioassay. Vet Parasitol. 2007;144:344-8.

35. Nordenfors H, Höglund J, Tauson R, Chirico J. Effects of permethrin impregnated plastic strips on Dermanyssus gallinae in loose housing systems for laying hens. Vet Parasitol. 2001;102:121-31.

36. Beugnet F, Chauve C, Gauthey M, Beert L. Resistance of the red poultry mite to pyrethroids in France. Vet Rec. 1997;140:577-9.

37. Marangi M, Cafiero MA, Capelli G, Camarda A, Sparagano OAE, Giangaspero A. Evaluation of the poultry red mite, Dermanyssus gallinae (Acari: Dermanyssidae) susceptability to some acaricides in field populations from Italy. Exp Appl Acarol. 2009;48:11-8.

38. Guy JH, Khajavi M, Hlalele MM, Sparagano O. Red mite (Dermanyssus gallinae) prevalence in laying units in Northern England. Br Poultry Sci. 2004:45:5-6.

39. Maurer V, Perler E. Silicas for control of the poultry red mite Dermanyssus gallinae. In: Proceedings of the European Joint Organic Congress: 30-31 May; Odense. 2006. p. 504-5.

40. Zeman P, Stika V, Skalka B, Bartik M, Dusbabek F, Lavickova M. Potential role of Dermanyssus gallinae De Geer, 1778 in the circulation of the agent of pullurosis-typhus in hens. Folia Parasitol. 1982;29:371-4.

41. Petrov D. Study on the gamasid red mite of poultry, Dermanyssus gallinae, as a carrier of Pasteurella multocida. Vet Med Nauki. 1975;12:32-6.

42. Chirico J, Eriksson H, Fossum O, Jansson D. The poultry red mite, Dermanyssus gallinae, a potential vector of Erysipelothrix rhusiopathiae causing erysipelas in hens. Med Vet Entomol. 2003;17:232-4.

43. Grebenyuk RV, Chirov PA, Kadysheva AM. The role of wild animals and blood-sucking arthropods in the epizootiology of infection with Listerioza. In: Frunze, Kirghiz, SSR; Izdatel'stvo Ilim. Institut Biologii, Akademiya Nauk Kirgizskoi SSR, Frunze, Kirghiz, SSR. 1972.

44. Zemskaya AA, Pchelkina AA. Gamasoid mites and Q fever. In: Markevich AP, editor. Problemy Parazitologii. Kiev. 1967. p. 258-9.

45. Arzey G. Mechanism of spread of Newcastle disease. New South Wales Agriculture and Fisheries Bulletin. 1990;42:12.

46. Shirnov FB, Ibragimova Al, Misirov ZG. The dissemination of the fowl-pox by the mite Dermanyssus gallinae. Veterinarya. 1972:4:48-9.

47. Hoffmann G. Vogelmilben als lästlinge, krankheitserzeuger und vektoren bei mensch und nutztier. Dtsch Tierärztl Wschr. 1987;95:7-10.

48. Smith MG, Blattner RJ, Heys FM. The isolation of the St. Louis Encephalitis virus from chicken mites (Dermanyssus gallinae) in nature. Science. 1944;100:362-3.

49. Smith MG, Blattner RJ, Heys FM. St. Louis encephalitis: Infection of chicken mites, Dermanyssus gallinae, by feeding on chickens with viraemia; transovarian passage of virus into the second generation. J Exp Med. 1946:84:1-6.

50. Chamberlain RW, Sikes RK, Sudia RW. Attempted laboratory infection of bird mites with the virus of Saint Louis encephalitis. American J Trop Med Hyg. 1957;6:1047-53.

51. Wegner Z. Laboratory study on some parasitic hematophagous arthropods as possible subsidiary links of the biocenosis of tick-borne encephalitis. Bull Inst Marit Trop Med Gdynia. 1976;27:75-85.

52. Durden LA, Linthicum KJ, Monath TP. Laboratory transmission of eastern equine encephalomyelitis virus to chickens by chicken mites (Acari: Dermanyssidae). J Med Entomol. 1993;30:281-5.

53. Chamberlain RW, Sikes RK. Laboratory investigations on the role of bird mites in the transmission of eastern and western equine encephalitis. Am J Trop Med Hyg. 1955;4:106-18.
54. Durden LA JLK, Turell MJ. Mechanical transmission of Venezuelan equine encephalomyelitis virus by haematophagous mites (Acari). J Med Entomol. 1992;29:118-21.

55. Valiente Moro C, De Luna CJ, Tod A, Guy JH, Sparagano OA, Zenner L. The poultry red mite (Dermanyssus gallinae): a potential vector of pathogenic agents. Exp Appl Acarol. 2009;48:93-104.

56. Circella E, Pugliese N, Todisco G, Cafiero MA, Sparagano OA, Camarda A. Chlamydia psittaci infection in canaries heavily infested by Dermanyssus gallinae. Exp Appl Acarol. 2011;55:329-38.

57. Ramsay G, Mason P, Hunter A. Chicken mite (Dermanyssus gallinae) infesting a dog. New Zeal Vet J. 1975;23:155.

58. Grant DI. Parasitic skin diseases in cats. J Small Anim Pract. 1989;30:250-4.

59. Declerq J, Nachtegaele L. Dermanyssus gallinae infestation in a dog. Canine Pract. 1993;18:34-6.

60. Mignon B, Losson B. Dermatitis in a horse associated with the poultry mite (Dermanyssus gallinae). Vet Dermatol. 2008;19:38-43.

61. Dorny P, Van Wyngaarden T, Vercruysse J, Symoens C, Jalia A. Survey on the importance of mange in the aetiology of skin lesions in goats in Peninsular Malaysia. Trop Anim Health Pro. 1994;26:81-6.

62. Allymehr M, Tavassoli M, Manoochehri MH, Ardavan D. Ectoparasites and gastrointestinal helminths of house mice (Mus musculus) from poultry houses in northwest Iran. Comp Parasitol. 2012;79:283-7.

63. Sikes RK, Chamberlain RW. Laboratory observations on three species of bird mites. Journal Parasitol. 1954;40:691-7.

64. Lucky AW, Sayers C, Argus JD, Lucky A. Avian mite bites acquired from a new source - pet gerbils: Report of 2 cases and review of the literature. Arch Dermatol. 2001;137:167-70.

65. Kirkwood AC. In vitro feeding of Dermanyssus gallinae. Exp Parasitol. 1971:29:1-6.

66. Gavrilovic P, Kecman V, Jovanovic M. Diagnosis of skin lesions caused by Dermanyssus gallinae in five patients. Int J Dermatol. 2015;54:207-10.

67. Cafiero MA, Galante D, Camarda A, Giangaspero A, Sparagano O. Why dermanyssosis should be listed as an occupational hazard. Occup Environ Med. 2011;68:628.

68. Williams RW. An infestation of a human habitation by Dermanyssus gallinae (DeGeer, 1778) (Acarina: Dermanyssidae) in New York City resulting in sanguisugent attacks upon the occupants. Am J Trop Med Hyg. 1958;7:627-9.

69. Pampiglione S, Pampiglione G, Pagani M, Rivasi F. Persistent scalp infestation by Dermanyssus gallinae in an Emilian country-woman. Parassitologia. 2001:43:113-5.

70. Lodha KR. The occurrence of tropica fowl mite, Ornithonyssus (Bdellonyssus, Liponyssus) bursa on man in Rajasthan (India). Vet Rec. 1969;84:363-5.

71. Toomey N. Gamasoidosis (fowl mite dermatitis) (Dermanyssus gallinae). Urol Cutan Rev. 1921;24:705-10.

72. Anon. Gamasoidosis. Lancet. 1922;199:90.

73. Litwin SB. "Pigeon mites" causing a pruritic dermatitis. Report of a case. JAMA. 1961;177:714-6.

74. Melter O, Arvand M, Votypka J, Hulinska D. Bartonella quintana transmission from mite to family with high socioeconomic status. Emerg Infect Dis. 2012;18:163-5.

75. George D, Finn R, Graham K, Mul M, Sparagano O. Of mites and men: preliminary evidence for increasing incidence of avian ectoparasitosis in humans and support of its potential threat to medical health. In: XVIIIth World Congress of the World Veterinary Poultry Association; August 19-23 Aug; Nantes. 2013. p. 635-6.

76. Sulzberger MB, Kaminstein I. Avian itch mites as a cause of human dermatoses. Arch Dermatol Syphilol. 1936;33:60-72.

77. Shaw JW, Pommerening RA. Avian mite dermatitis (gamasoidosis). Arch Dermatol Syphilol. 1955;61:466-8.

78. Rockwell E. Dermatitis due to Dermanyssus gallinae of pigeons. AMA Arch Derm. 1953;68:82.

79. DeOreo GA. Pigeons acting as vector in acariasis caused by Dermanyssus gallinae (DeGeer, 1778). AMA Arch Derm. 1958;77:422-9.

80. Winkler A. Endemie durch Vogelmilben (Dermanyssus gallinae) in einem Krankenhaus. Dermatol Wochenschr. 1967;16:458-9.

81. Rosen S, Yeruham I, Braverman Y. Dermatitis in humans associated with the mites Pyemotes tritici, Dermanyssus gallinae, Ornithonyssus bacoti and Androlaelaps casalis in Israel. Med Vet Entomol. 2002;16:442-4.

82. Cafiero MA, Camarda A, Circella E, Santagada G, Schino G, Lomuto M. Pseudoscabies caused by Dermanyssus gallinae in Italian city dwellers: a 
new setting for an old dermatitis. J Eur Acad Dermatol Venereol. 2008:22:1382-3.

83. Akdemir C, Gulcan E, Tanritanir P. Case report: Dermanyssus gallinae in a patient with pruritus and skin lesions. Turkiye Parazitol Derg. 2009;33:242-4

84. Haag-Wackernagel D, Bircher AJ. Ectoparasites from feral pigeons affecting humans. Dermatology. 2010;220:82-92.

85. Prins $M$, Go $\mid H$, Van Dooren-Greebe RJ. Parasitic pruritus: bird mite zoonosis. Ned Tijdschr Geneeskund. 1996;140:2550-2.

86. Baselga E, Drolet BA, Esterly NB. Avian mite dermatitis. Pediatrics. 1996:97:743-5.

87. Fuentes M, Sainz-Elipes S, Saez-Duran S, Galan-Puchades M. Human ectoparasitism due to the poultry red mite, Dermanyssus gallinae, in the city of Valencia (Spain) and its surroundings. Rev Ibero-Latinoam Parasitol. 2009:68:188-91.

88. Collgros H, Iglesias-Sancho M, Aldunce MJ, Exposito-Serrano V, Fischer C, Lamas N, et al. Dermanyssus gallinae (chicken mite): an underdiagnosed environmental infestation. Clin Exp Dermatol. 2013:38:374-7.

89. Abdigoudarzi M, Mirafzali MS, Belgheiszadeh H. Human infestation with Dermanyssus gallinae (Acari: Dermanyssidae) in a family referred with pruritus and skin lesions. J Arthropod-Borne Dis. 2013;8:119-23.

90. Regan AM, Metersky ML, Craven DE. Nosocomial dermatitis and pruritus caused by a pigeon mite infestation. Arch Intern Med. 1987;147:2185-7.

91. Sexton DJ, Haynes B. Bird-mite infestation in a university hospital. Lancet 1975;305:445.

92. Auger P, Nantel J, Meunier N, Harrison RJ, Loiselle R, Gyorkos TW. Skin acariasis caused by Dermanyssus gallinae (de Geer): an in-hospital outbreak. Can Med Assoc J. 1979;120:700-3.

93. Neill SM, Monk BE, Pembroke AC. Gamasoidosis - avian mite dermatitis (Dermanyssus gallinae). Brit J Dermatol. 1985;113:44-4.

94. Vargo JA, Ginsberg MM, Mizrahi M. Human infestation by the pigeon mite: a case report. Am J Infect Control. 1983;11:24-5.

95. Bellanger AP, Bories C, Foulet F, Bretagne S, Botterel F. Nosocomial dermatitis caused by Dermanyssus gallinae. Infect Control Hosp Epidemiol. 2008;29:282-3.

96. Kowalska M, Kupis B. Gamasoidosis (gamasidiosis) - not infrequent skin reactions, frequently unrecognized. Pol Med Sci Hist Bull. 1976;15-16:391-4.

97. Bardach H. Acaraiasis due to Dermanyssus gallinae (gamasoidosis) in Vienna. A Hautkr. 1981:56:21-6.

98. Rossiter A. Occupational otitis externa in chicken catchers. J Laryngol Otol. 1997:111:366-7.

99. Lodde B, Bizien-Le Dez V, Roguedas-Contios AM, Misery L, Dewitte JD. An itchy occupational disease affecting a poultry farmer due to bites from Dermanyssus gallinae: Effect of sensitization to Dermanyssus pteronyssinus. Arch Mal Prof Enviro. 2012;73:51-61.

100. Naltsas S, Hodge SJ, Gataky Jr GJ, Owen LG. Eczematous dermatitis caused by Dermanyssus americanus. Cutis. 1980;25:429-31.

101. Uesugi Y, Aiba S, Suetake T, Tagami H. Multiple infestations with avian mites within a family. Int J Dermatol. 1994;33:566-7.

102. Desoubeaux G, Amara M, Goustille J, Chandenier J. Bioorganic farming practices as a source of atypical ectoparasitosis. Arch Dermatol. 2011:147:1458-9.

103. Cahn MM, Shechter FR. Pruritus from an unusual source-bird mites; report of a case. J Am Med Assoc. 1958;167:724-6.

104. Martalock DL. "Bugs". Arch Dermatol. 1971;103:339.

105. Braun 3rd M. Avian mite dermatitis. Cutis. 1979;23:680-2.

106. Congly H. Northern fowl mite dermatitis. Can Med Assoc J. 1985;132:738.

107. Orton DI, Warren LJ, Wilkinson JD. Avian mite dermatitis. Clin Exp Dermatol. 2000;25:129-31.

108. Watson CR. Human infestation with bird mites in Wollongong. Commun Dis Intell. 2003:27:259-61.

109. Kong TK, To WK. Images in clinical medicine. Bird-mite infestation N Engl J Med. 2006;354:1728.

110. Gupta AK, Billings JK, Ellis CN. Chronic pruritus: an uncommon cause. Avian mite dermatitis caused by Ornithonyssus sylviarum (Northern fowl mite). Arch Dermatol. 1988;124:1102-3.

111. Miamoto K, Sakaino T. Two cases of dermatitis caused by the northern fowl mite, Ornithonyssus sylviarum, in Asahikawa, Japan. Med Entomol. 1997:48:265-7.

112. Mazyad SA, Abel El-Kadi M. Ornithonyssus (Acari: Macronyssidae) mite dermatitis in poultry field-workers in Almarg, Qalyobiya governorate. J Egypt Soc Parasitol. 2005;35:213-22.
113. Shaw JW, Pommerening RA. Avian mite dermatitis, gamasoidosis; report of a case. Arch Derm Syphilol. 1950;61:466-9.

114. McGinniss GF. Avian-mite dermatitis - report of a case. New Eng J Med. 1959;261:396-7.

115. Hidano A, Asanuma K. Letter: Acariasis caused by bird mites. Arch Dermatol. 1976;112:881-2

116. Schulze KE, Cohen PR. Dove-associated gamasoidosis: a case of avian mite dermatitis. J Am Acad Dermatol. 1994;30:278-80.

117. Marangi M, De Luna CJ, Cafiero MA, Camarda A, Le Bouquin S, Huonnic D, et al. Phylogenetic relationship between Dermanyssus gallinae populations in European countries based on mitochondrial COI gene sequences. Exp Appl Acarol. 2014;48:143-55.

118. Roy L, Dowling APG, Chauve CM, Buronfosse T. Delimiting species boundaries within Dermanyssus Duges, 1834 (Acari:Dermanyssidae) using a total evidence approach. Mol Phylogenet Evol. 2009:50:446-70.

119. Oines O, Brannstrom S. Molecular investigations of cytochrome c oxidase subunit I (COI) and the internal transcribed spacer (ITS) in the poultry red mite, Dermanyssus gallinae, in northern Europe and implications for its transmission between laying poultry farms. Med Vet Entomol. 2011;25:402-12.

120. Chen W, Plewig G. Human demodicosis: revisit and a proposed classification. Brit J Dermatol. 2014;170:1219-25.

121. Beroiz B, Couso-Ferrer F, Ortego F, Chamorro MJ, Arteaga C, Lombardero M, et al. Mite species identification in the production of allergenic extracts for clinical use and in environmental samples by ribosomal DNA amplification. Med Vet Entomol. 2014;28:287-96

122. Harrington DW, Robinson K, Sparagano OA. Immune responses of the domestic fowl to Dermanyssus gallinae under laboratory conditions. Parasitol Res. 2010;106:1425-34.

123. Wambier CG, Wambier SP. Gamasoidosis illustrated - from the nest to dermoscopy. An Bras Dermatol. 2012;87:926-7.

124. Roberts LJ, Huffam SE, Walton SF, Currie BJ. Crusted scabies: clinical and immunological findings in seventy-eight patients and a review of the literature. J Infect. 2005:50:375-81.

125. Niyonsaba F, Ogawa H. Protective roles of the skin against infection: implication of naturally occurring human antimicrobial agents beta-defensins, cathelicidin LL-37 and lysozyme. J Dermatol Sci. 2005:40:157-68.

126. Bernier UR, Tsikolia M, Agramonte NM. Discovery of mosquito attractants and attraction-inhibitors. In: 246th American Chemical Society National Meeting \& Exposition. 2013. p. 89

127. Harrington DW, Guy JH, Robinson K, Sparagano OA. Comparison of synthetic membranes in the development of an in vitro feeding system for Dermanyssus gallinae. Bull Entomol Res. 2010;100:127-32.

128. Dukas R. Evolutionary biology of insect learning. Ann Rev Entomol. 2008;53:145-60.

129. George DR, Sparagano OA, Port G, Okello E, Shiel RS, Guy JH. Environmental interactions with the toxicity of plant essential oils to the poultry red mite Dermanyssus gallinae. Med Vet Entomol. 2010:24:1-8.

130. George DR, Shiel RS, Appleby WG, Knox A, Guy JH. In vitro and in vivo acaricidal activity and residual toxicity of spinosad to the poultry red mite, Dermanyssus gallinae. Vet Parasitol. 2010;173:307-16.

\section{Submit your next manuscript to BioMed Central and take full advantage of:}

- Convenient online submission

- Thorough peer review

- No space constraints or color figure charges

- Immediate publication on acceptance

- Inclusion in PubMed, CAS, Scopus and Google Scholar

- Research which is freely available for redistribution 